\title{
PROCESSES OF STRUCTURE AND PHASE FORMATION OF AERATED CONCRETE OF NON-AUTOCLAVE HARDENING CONTAINING FERROSILICON AS A GASIFIER
}

\author{
Ukrainian State University of Chemical Technology, Dnipro, Ukraine
}

\begin{abstract}
The paper deals with the structure and phase composition of non-autoclave aerated concrete with a density of $600-800 \mathrm{~kg} \mathrm{~m}^{-3}$ using ferrosilicon as a gasifier. The conditions of formation of porous structure of aerated concrete and preparation of calcium hydrosilicates were considered. Phase composition of the samples was investigated by means of X-ray phase analysis and differential thermal analysis. Analysis of X-ray patterns showed that the test samples contained tobermorite $11.3 \AA\left(5 \mathrm{CaO} \cdot 6 \mathrm{SiO}_{2} \cdot 5.5 \mathrm{H}_{2} \mathrm{O}\right)$, xonotlite $\left(6 \mathrm{CaO} \cdot 6 \mathrm{SiO}_{2} \cdot \mathrm{H}_{2} \mathrm{O}\right)$ and $\alpha$-dicalcium silicate hydrate $\left(2 \mathrm{CaO} \cdot \mathrm{SiO}_{2} \cdot \mathrm{H}_{2} \mathrm{O}\right)$ as a binder. It was established that there is an increase in the content of hydrosilicate phases with an increase in the content of gasifier in the vast majority of cases. The obtained data were confirmed by the results of differential thermal analysis.
\end{abstract}

Keywords: ferrosilicon, aerated concrete, gasifier, phase composition, calcium hydrosilicates.

DOI: $10.32434 / 0321-4095-2021-139-6-45-50$

\section{Introduction}

One of the main tasks of the construction industry is to expand the range of available and develop new building materials and products, reduce energy and material consumption of production, ensure savings of binders and increase the quality of products based on them. Autoclaved aerated concrete is the most popular material in the construction market as of today. It combines high thermal insulation and structural properties. The properties largely affect the quality of the structure and durability of cellular concrete. The quality of the structure is influenced by the compositions and methods of manufacturing aerated concrete. Aerated concretes mainly consist of closed pores $0.2-2.0 \mathrm{~mm}$ in size $(60-85 \%)$. The shape of the pores is a parameter that characterizes the degree of deformation of spherical pores into regular polyhedra. An increase in cellular porosity of system, a decrease in surface tension, an increase of stability of the mass and a rapid fixation of the structure by hardening lead to molding polyhedra pores. The higher the porosity, the more precise the polyhedra shape should be. Conditions for the formation of a porous structure were investigated earlier [1]. The method was based on the following main statements that reflect the dependences of the properties of aerated concrete on its structure: (i) the initial mixtures should contain a minimum amount of water in order to obtain the densest and strongest walls of the pores; (ii) pores should have the densest packing at their maximum ratio to the pore volume from evaporated free water; and (iii) the volume of the mixture should be sufficient for filling the interporous space. Saley et al. [2] studied the factors determining the structure of cellular concrete; it was concluded that the kinetics of gas evolution and change in time of structural and mechanical properties of the mixture have a decisive influence on the properties of the material.

Korolev et al. [3] and Gorshkov et al. [4] examined the issue of optimizing the composition and structure of structural and heat-insulating aerated concrete. They proposed a calculation model which is reduced to solving a system of equations in which the strength at compression of aerated concrete can be represented as a maximum ratio load to the area of the elementary cell.

As is known, the structure of aerated concrete mainly consists of hydrate and silicon-containing components. The main hydrate phases formed in aerated concrete are calcium hydrosilicates, in particular tobermorite $11.3 \AA\left(5 \mathrm{CaO} \cdot 6 \mathrm{SiO}_{2} \cdot 5.5 \mathrm{H}_{2} \mathrm{O}\right)$ and xonotlite $\left(6 \mathrm{CaO} \cdot 6 \mathrm{SiO}_{2} \cdot \mathrm{H}_{2} \mathrm{O}\right)$ [4-8].

The aim of the work is to study the process of formation of the structure and determine mineralogical composition of aerated concrete 
products of non-autoclave hardening, which contain a gasifier based on ferrosilicon.

\section{Experimental}

The examined samples of aerated concrete were produced from the following materials: Portland cement clinker, gypsum stone, lime, river sand, ferrosilicon and caustic soda. Testing of compositions was conducted for several compositions shown in Table.

\section{Compositions of aerated concrete}

\begin{tabular}{c|c|c|c}
\hline \multirow{2}{*}{ Composition } & \multicolumn{3}{|c}{$\begin{array}{c}\text { The content of aerated concrete } \\
\text { components, wt.\% }\end{array}$} \\
\cline { 2 - 4 } & cement & sand & lime \\
\hline 1 & 32 & 52 & 16 \\
\hline 2 & 35 & 54 & 11 \\
\hline
\end{tabular}

The phase composition of non-autoclaved aerated concrete was investigated using complex $\mathrm{X}$-ray phase and differential thermal (DTA) analyses. The identification of X-ray peaks, endo- and exothermic effects on DTA curves were performed using reference data given elsewhere [4]. X-ray phase analysis was performed by diffraction patterns powder obtained on an automatic diffractometer DRON-3, using X-ray tube with cobalt and copper anticathode. Thermal stability of the samples was investigated ona
Q-1500D derivatograph of the Paulik-Paulik-Erdey system in the temperature range of $20-900^{\circ} \mathrm{C}$ with the rate of temperature rise of $10 \mathrm{deg} \mathrm{min}^{-1}$. Exposed samples were ground to a full passage through a sieve No. 0063.

\section{Results and discussion}

The macrostructure of aerated concrete with a density of $600-800 \mathrm{~kg} \mathrm{~m}^{-3}$ reveals uniform porous structure with sustained pore sizes from 0.3 to $1.5 \mathrm{~mm}$, which form a hollow structure represented by pores of oval or round shape without shells or cracks on the surface of the interporous septa (Fig. 1). The polydisperse nature of the pore distribution is ensured by the uniform distribution of smaller pores between large pores.

Non-autoclaved aerated concrete is made using Portland cement. Thus, the processes of setting and hardening of cement in the presence of components of the porous mass determine the mineral composition of newly formed structures and properties of products [9-12].

Analyzing the results of calculations of the number of interporous walls and pores in nonautoclaved aerated concrete (Figs. 1 and 2), we can see the following:

- when the content of ferrosilicon is $3 \mathrm{wt} . \%$, the number of pores and walls is about $40 \%$ and

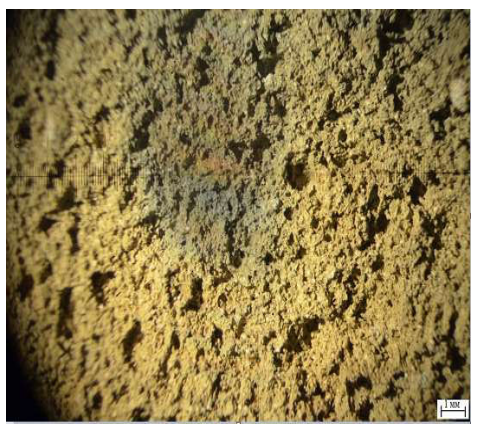

a

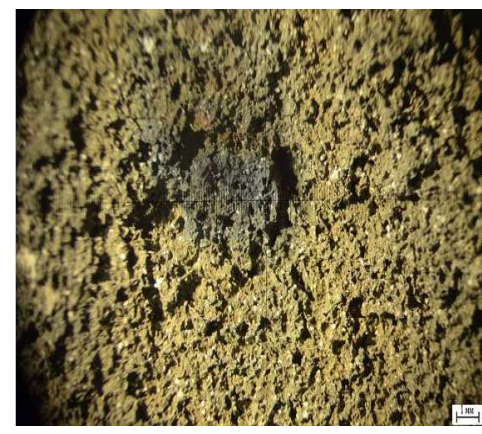

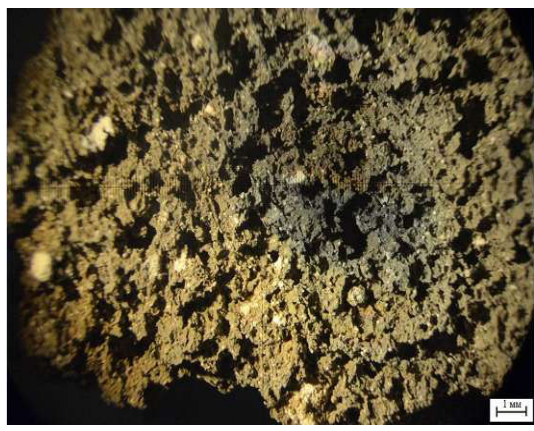

Fig. 1. Macrostructure of non-autoclaved aerated concrete with FeSi as a gasifier (composition 1) at different content of ferrosilicon (wt.\%): $\mathrm{a}-3 ; \mathrm{b}-4$ and $\mathrm{c}-5$

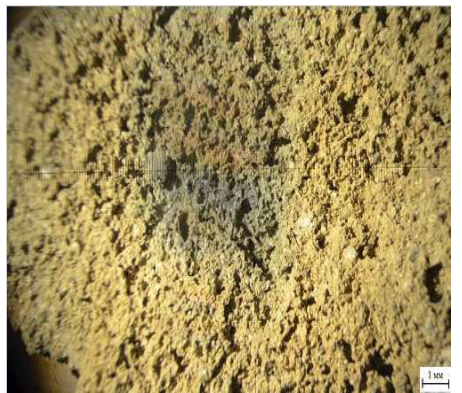

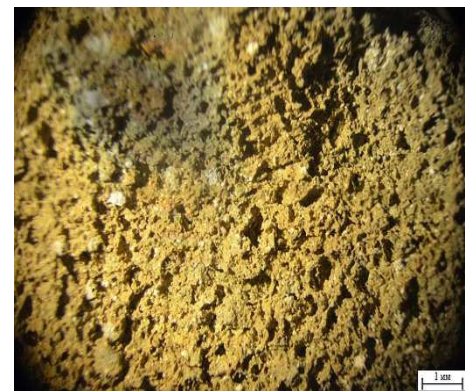

b

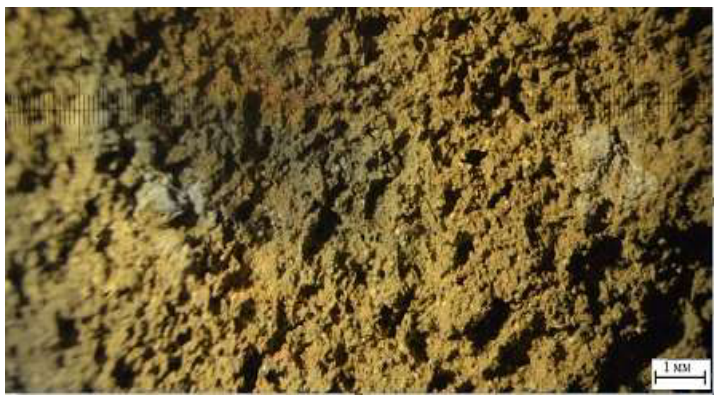

Fig. 2. Macrostructure of non-autoclaved aerated concrete with FeSi as a gasifier (composition 2) at different content of ferrosilicon (wt.\%): $\mathrm{a}-3 ; \mathrm{b}-4$ and $\mathrm{c}-5$ 

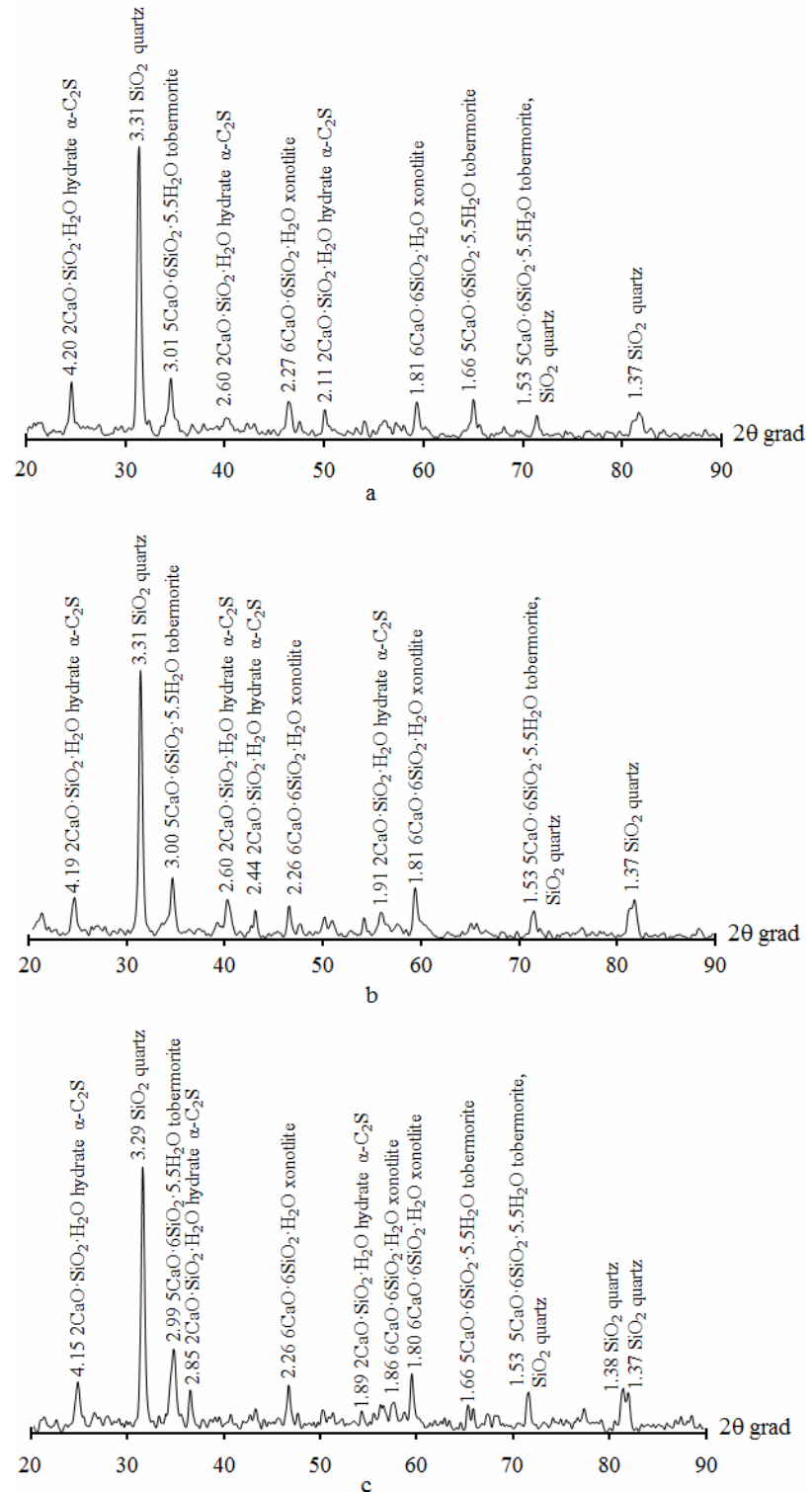

Fig. 3. X-ray patterns of aerated concrete compositions (composition 1) with $\mathrm{FeSi}$ as a gasifier at different content of ferrosilicon (wt.\%): $a-3 ; b-4$ and $c-5$

$60 \%$, respectively (Figs. 1,a and 2,a);

- when the content of ferrosilicon is 4 wt.\%, the number of pores and walls is approximately $46 \%$ and $54 \%$, respectively (Figs. 1,b and 2,b);

- when the content of ferrosilicon is $5 \mathrm{wt} . \%$, the number of pores and walls is about $65 \%$ and $35 \%$, respectively (Figs. 1,c and 2,c).

Thus, the increase in the content of ferrosilicon as a gasifier resulted in an increase in the pore space of the aerated concrete composition.

In order to establish the mineralogical composition of aerated concrete compositions containing ferrosilicon as a gasifier, $\mathrm{X}$-ray phase
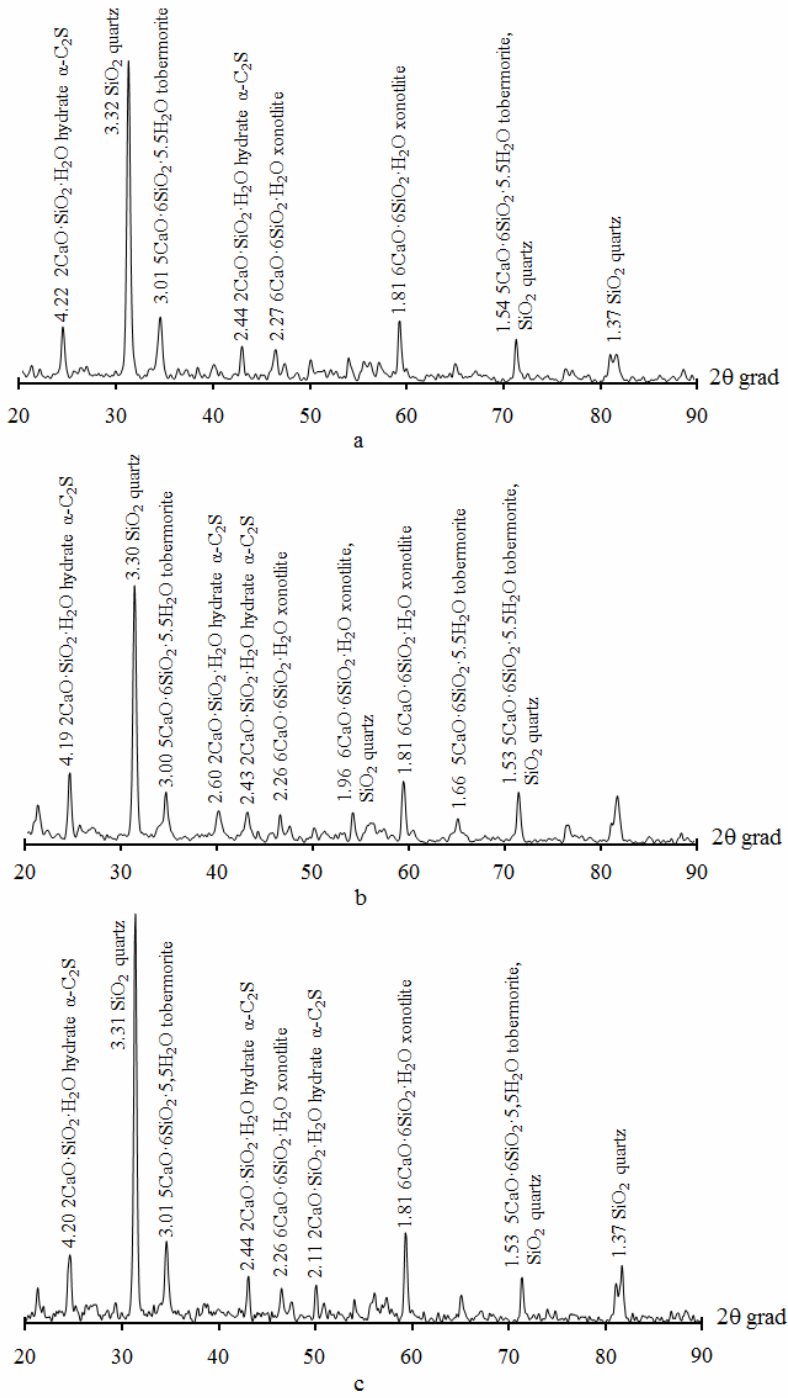

Fig. 4. X-ray patterns of aerated concrete compositions (composition 2) with $\mathrm{FeSi}$ as a gasifier at different content of ferrosilicon (wt.\%): $\mathrm{a}-3 ; \mathrm{b}-4$ and $\mathrm{c}-5$

analysis was performed, the results of which are presented in Figs. 3 and 4.

Analysis of X-ray patterns showed that the studied samples contain tobermorite $11.3 \AA$ $\left(5 \mathrm{CaO} \cdot 6 \mathrm{SiO}_{2} \cdot 5.5 \mathrm{H}_{2} \mathrm{O}\right)$, xonotlite $\left(6 \mathrm{CaO} \cdot 6 \mathrm{SiO}_{2} \cdot \mathrm{H}_{2} \mathrm{O}\right)$ and $\alpha$-dicalcium silicate hydrate $\left(2 \mathrm{CaO} \cdot \mathrm{SiO}_{2} \cdot \mathrm{H}_{2} \mathrm{O}\right)$. It should be noted that there is an overlap of some peaks of tobermorite and quartz, in particular for $1.53 \AA$. In addition, the most intense peaks are observed for 3.29-3.32 $\AA$, which are characteristic of quartz. A small number of calcium hydrosilicate peaks in the X-ray patterns of non-autoclaved aerated concrete may indicate the presence of poorly crystallized and lime-rich gel (the so-called $\mathrm{C}-\mathrm{S}-\mathrm{H}$-gel), which is virtually unidentifiable and merges with a background line. 


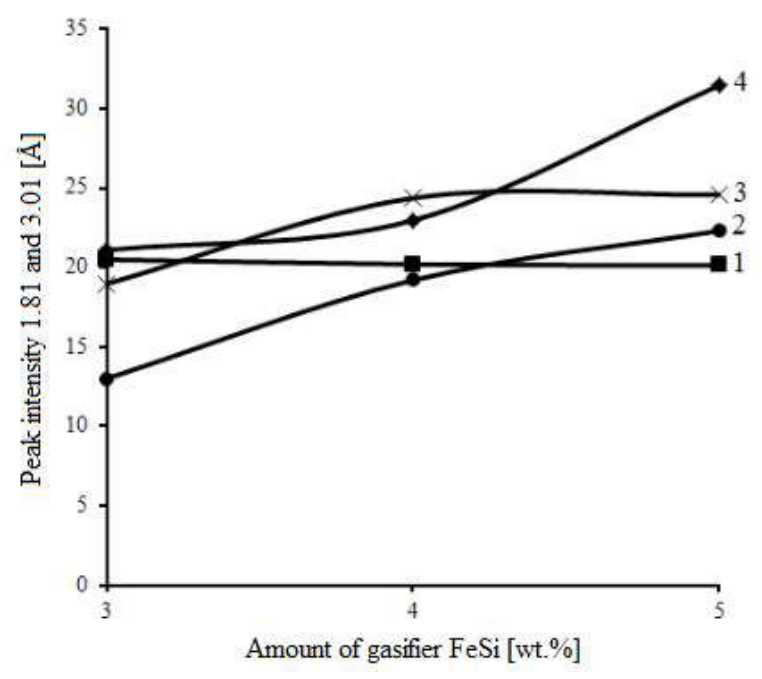

Fig. 5. Dependences of the intensity of peaks of hydrosilicates on the amount of FeSi: 1 - tobermorite at the peak of $3.01 \AA$

(composition 2); 2 - xonotlite at the peak of $1.81 \AA$

(composition 1); 3 - xonotlite at the peak of $1.81 \AA$

(composition 2); and 4 - tobermorite at the peak of $3.01 \AA$

(composition 1)

The dependences of the intensity of the most characteristic peaks of hydrosilicates on the amount of $\mathrm{FeSi}$ in the composition are plotted in Fig. 5.

There is an increase in the content of xonotlite with increasing the gasifier content from 3 to $5 \mathrm{wt} . \%$ for compositions 1 and 2 , as the intensity of its characteristic peaks increases (Fig. 4). For example, the peak of $1.81 \AA$ increases from 13.01 to 22.31 (by

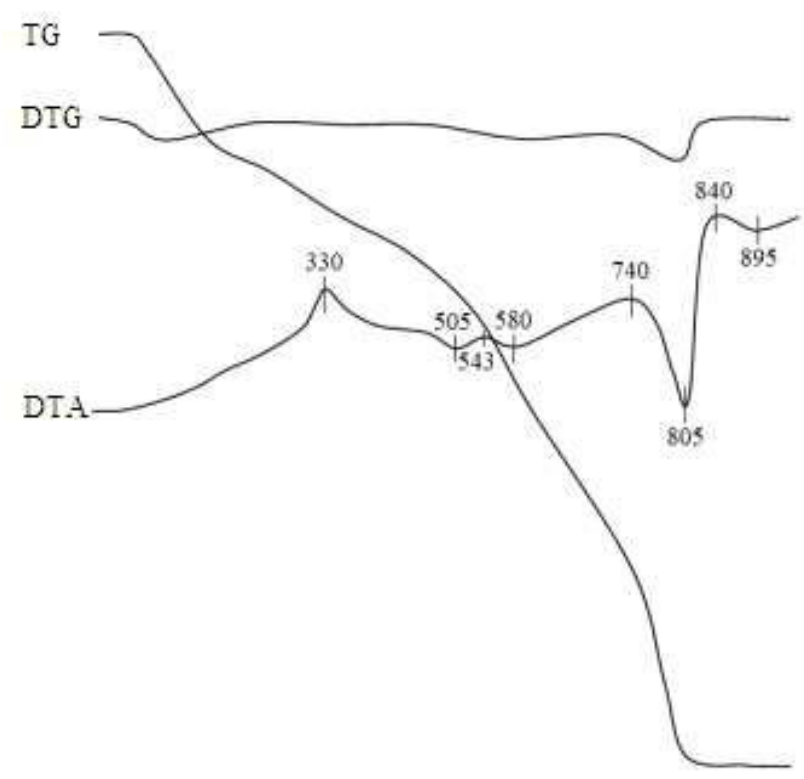

$42 \%$ ) and from 18.97 to 24.57 (by 23\%) for compositions 1 and 2, respectively.

A similar relationship is also observed in case of formation of tobermorite. Thus, the intensity of the peaks of $3.01 \AA$ characteristic of this mineral increases with increasing $\mathrm{FeSi}$ as a gasifier from 21.1 to 31.47 (by $33 \%$ ) for composition 1 . At the same time, the content of this hydrosilicate for composition 2 does not change.

Analyzing the presence of quartz, it should be noted that a clear relationship between the height of the peaks and the content of the gasifier is not observed.

The presence of hydrosilicates established by X-ray phase analysis is confirmed by DTA data (Fig. 6).

According to the data of thermogravimetric analysis, the average total weight loss of samples of compositions 1 and 2, which contain 5 wt. $\%$ of ferrosilicon, is $17 \%$. For them in the temperature range of $20-490^{\circ} \mathrm{C}$, there is a loss of about $33 \%$ of the weight of the sample. The weight loss of the sample at the temperature of up to $490^{\circ} \mathrm{C}$ is explained by the processes of oxidation and combustion of organic compounds (stearic acid and surfactants) and the removal of physically bound moisture. The main weight loss of the sample is about $67 \%$ in the temperature range of $490-805^{\circ} \mathrm{C}$. The endothermic effect at $580^{\circ} \mathrm{C}$ corresponds to the dehydration of portlandite $\mathrm{Ca}(\mathrm{OH})_{2}$ as well as the polymorphic conversion of $\beta$-quartz into $\alpha$-quartz. There is a dehydration of xonotlite, which is confirmed by the

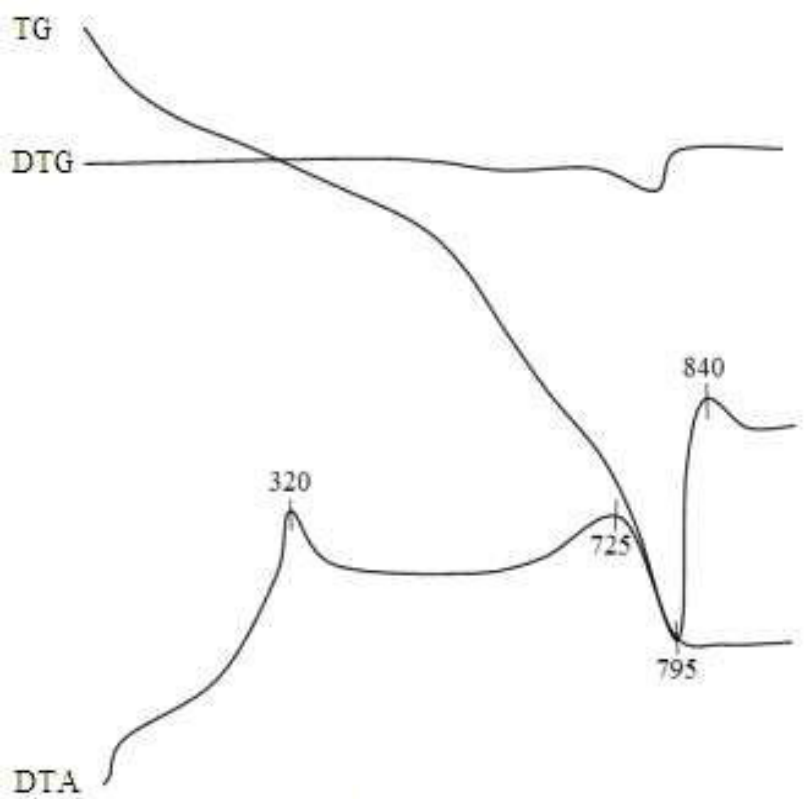

b

Fig. 6. Thermograms of aerated concrete compositions with FeSi as a gasifier: a - composition 1; b - composition 2 
endothermic effect on the DTA curves with a maximum at the temperatures of $795^{\circ} \mathrm{C}$ and $805^{\circ} \mathrm{C}$ for compositions 1 and 2 , respectively. The exothermic effect at $830-840^{\circ} \mathrm{C}$ on both thermograms is due to the presence of tobermorite $11.3 \AA$, which loses residual water at this temperature, after which wollastonite crystallizes on its basis. An exothermic effect at $320^{\circ} \mathrm{C}$ and $330^{\circ} \mathrm{C}$ is also observed on the DTA curves of both samples, which cannot be precisely explained.

\section{Conclusions}

The use of ferrosilicon as a gasifier in the production of non-autoclaved aerated concrete allows forming dense and strong interporous partitions and uniform fine-porous structure of the material. An increase in the content of ferrosilicon in the range of $3-5$ wt.\% in the composition leads to a symbate increase in the volume of the pore component by 35-40\%. Various methods of analysis showed that the phase composition of aerated concrete with $\mathrm{FeSi}$ as a gasifier is represented mainly by tobermorite $\left(5 \mathrm{CaO} \cdot 6 \mathrm{SiO}_{2} \cdot 5.5 \mathrm{H}_{2} \mathrm{O}\right)$, xonotlite $\left(6 \mathrm{CaO} \cdot 6 \mathrm{SiO}_{2} \cdot \mathrm{H}_{2} \mathrm{O}\right)$ and $\alpha$-dicalcium silicate hydrate $\left(2 \mathrm{CaO} \cdot \mathrm{SiO}_{2} \cdot \mathrm{H}_{2} \mathrm{O}\right)$, which act as binder components, as well as unbound quartz $\left(\mathrm{SiO}_{2}\right)$ as a filler. It should also be noted that the formation of these calcium hydrosilicates is more intense in samples with reduced specific gravity, which correlates well with the data obtained by Kaftaeva et al. [13].

\section{REFERENCES}

1. Sakharov G.P. Obrazovaniye optimalnoi struktury yacheistogo betona // Stroitelnyye materialy. - 1973. - No. 10 - P.30-33.

2. Doslidzhennya vplyvu dyspersnosti komponentiv gazobetonu na yogo osnovni budivelni vlastyvosti / Saley A., Sigunov A., Kravchenko T., Khmarska L. // Voprosy Khimii i Khimicheskoi Tekhnologii. - 2015. - No. 5 - P.75-78.

3. Korolev A.S., Voloshin E.A., Trofimov B.Ya. Optimizatsiya sostava i struktury konstruktsionno-teploizolyatsionnogo yacheistogo betona // Stroitelnyye materialy. - 2004. - No. 3 P.30-32.

4. Gorshkov V.S., Timashev V.V., Savelyev V.G. Metody fiziko-khimicheskogo analiza vyazhushchikh veshchestv. - M.: Vysshaya Shkola, 1981. - $335 \mathrm{p}$.

5. Thermodynamic analysis of chemical reactions in the systems $\mathrm{FeSi}-\mathrm{Ca}(\mathrm{OH})_{2}-\mathrm{H}_{2} \mathrm{O}$ and $\mathrm{FeSi}_{2}-\mathrm{Ca}(\mathrm{OH})_{2}-\mathrm{H}_{2} \mathrm{O} /$ Musina A.O., Sihunov O.O., Kravchenko T.V., Hura A.O. // Voprosy Khimii i Khimicheskoi Tekhnologii. - 2019. - No. 6. P.136-143.
6. Termodinamicheskii analiz reaktsij v sisteme $\mathrm{Si}-\mathrm{Ca}(\mathrm{OH})_{2}$ / Salej A.A., Snezhko L.A., Sigunov A.A., Kravchenko T.V., Hmarskaja L.A., Kononovich M.N. // Vestnik NaTs. Tekhn. Un-ta «KhPI». - 2015. - No. 30(1139). - P.85-91.

7. Research into influence of the electrolysis modes on the composition of galvanic Fe-Co-Mo coatings / Yermolenko I, Ved' M, Karakurkchi A, Proskurina V, Sknar I, Kozlov Y, et al. // Eastern-Eur. J. Enterprise Technol. - 2017. - Vol.3. - No. 12(87). - P.9-15.

8. Minakova N.A., Zaichuk A.V., Belyi Y.I. The structure of borate glass // Glas. Ceram. - 2008. - Vol.65. - P.70-73.

9. Butt Yu.M. Khimicheskaya tekhnologiya vyazhushchikh materialov. - M.: Vysshaya Shkola, 1980. - 472 p.

10. Kasymova M.T., Dyykanbaeva N.A. Issledovaniye struktury i fazovogo sostava neavtoklavnogo gazobetona // Izvestiya Vuzov. Stroitelstvo. - 2019. - No. 7. - P.16-22.

11. Modified alumina cement with high service properties / Logvinkov S.M., Shabanova G.N., Korohodska A.N., Khrystych E.V. // China's Refract. - 2016. - Vol.25. - No. 4. - P.1-5.

12. Dolotova R.G., Vereshchagin V.I., Smirenskaya V.N. Protsessy fazoobrazovaniya i formirovaniya poristoi struktury gazobetona na osnove portlandtsementa $\mathrm{s}$ ispolzovaniem polevoshpatovo-kvartsevogo peska i volokon asbesta // Izvestiya Tomskogo Politekhnicheskogo Universiteta. - 2011. - No. 3. P.47-51.

13. Kaftaeva M.V., Rakhimbaev S.M., Pospelova E.A. Issledovanie fazovogo sostava avtoklavnykh yacheistykh betonov // Sovremennyye problemy nauki i obrazovaniya. -2013 . - No. 5.

Received 09.09.2021

\section{ПРОЦЕСИ СТРУКТУРО- І ФАЗОУТВОРЕННЯ ГАЗОБЕТОНУ НЕАВТОКЛАВНОГО ТВЕРДІННЯ 3 ФЕРОСИЛЩІЕМ В ЯКОСТІ ГАЗОУТВОРЮВАЧА}

\section{А.О. Мусіна, О.О. Сігунов, О.П. Рижова,}

О.С. Свердліковська, А.О. Гура

Надано результати досліджень структури і фазового складу неавтоклавного газобетону щільністю 600-800 кг $/ \mathrm{M}^{3}$ 3 використанням феросиліцію як газоутворювача. Розглянуті умови формування пористої структури газобетону і утворення гідросилікатів кальцію. Здійснено дослідження фазового складу зразків за допомогою рентгенофазового та диференційно-термічного методів аналізу. Аналіз дифрактограм показав, що досліджені зразки містять як в'яжучі речовини тоберморит $11,3 \AA\left(5 \mathrm{CaO} \cdot 6 \mathrm{SiO}_{2} \cdot 5,5 \mathrm{H}_{2} \mathrm{O}\right)$, ксонотліт $\left(6 \mathrm{CaO} \cdot 6 \mathrm{SiO}_{2} \cdot \mathrm{H}_{2} \mathrm{O}\right)$ та $\alpha$-гідрат двухкальцієвого силікату $\left(2 \mathrm{CaO} \cdot \mathrm{SiO}_{2} \cdot \mathrm{H}_{2} \mathrm{O}\right)$. Встановлено, що в переважній кількості випадків спостерігається збільшення вмісту гідросилікатних фаз, зі збільшенням вмісту газоутворювача. Отримані дані підтверджуються результатами диференційно-термічного методу аналізу.

Ключові слова: феросиліцій, ніздрюватий бетон, газоутворювач, фазовий склад, гідросилікати кальцію. 


\section{PROCESSES OF STRUCTURE AND PHASE FORMATION OF AERATED CONCRETE OF NON-AUTOCLAVE HARDENING CONTAINING FERROSILICON AS A GASIFIER}

A.O. Musina, O.O. Sihunov *, O.P. Ryzhova,

\section{O.S. Sverdlikovska, A.O. Hura}

Ukrainian State University of Chemical Technology, Dnipro, Ukraine

*e-mail: alsigunov@ukr.net

The paper deals with the structure and phase composition of non-autoclave aerated concrete with a density of $600-800 \mathrm{~kg} \mathrm{~m}^{-3}$ using ferrosilicon as a gasifier. The conditions of formation of porous structure of aerated concrete and preparation of calcium hydrosilicates were considered. Phase composition of the samples was investigated by means of X-ray phase analysis and differential thermal analysis. Analysis of X-ray patterns showed that the test samples contained tobermorite $11.3 \AA\left(5 \mathrm{CaO} \cdot 6 \mathrm{SiO}_{2} \cdot 5.5 \mathrm{H}_{2} \mathrm{O}\right)$, xonotlite $\left(6 \mathrm{CaO} \cdot 6 \mathrm{SiO}_{2} \cdot \mathrm{H}_{2} \mathrm{O}\right)$ and $\alpha$-dicalcium silicate hydrate $\left(2 \mathrm{CaO} \cdot \mathrm{SiO}_{2} \cdot \mathrm{H}_{2} \mathrm{O}\right)$ as a binder. It was established that there is an increase in the content of hydrosilicate phases with an increase in the content of gasifier in the vast majority of cases. The obtained data were confirmed by the results of differential thermal analysis.

Keywords: ferrosilicon; aerated concrete; gasifier; phase composition; calcium hydrosilicates.

\section{REFERENCES}

1. Sakharov GP. Obrazovanie optimalnoi struktury yacheistogo betona [Formation of the optimal structure of cellular concrete]. Stroitelnyye Materialy. 1973; (10): 30-33. (in Russian).

2. Saley A, Sigunov A, Kravchenko T, Khmarska L. Doslidzhennya vplyvu dyspersnosti komponentiv gazobetonu na yogo osnovni budivelni vlastyvosti [Investigation on the influence of the dispersion of gas concrete components on main construction properties]. Voprosy Khimii i Khimicheskoi Tekhnologii. 2015; (5): 75-78. (in Ukrainian).

3. Korolev AS, Voloshin EA, Trofimov BYa. Optimizatsiya sostava i struktury konstruktsionno-teploizolyatsionnogo yacheistogo betona [Optimization of the composition and structure of structural and thermal insulation cellular concrete]. Stroitelnyye Materialy. 2004; (3): 30-32. (in Russian).

4. Gorshkov VS, Timashev VV, Savelyev VG. Metody fizikokhimicheskogo analiza vyazhushchikh veshchestv [Methods of physicochemical analysis of binders]. Moscow: Vysshaya Shkola; 1981. 335 p. (in Russian).
5. Musina AO, Sihunov OO, Kravchenko TV, Hura AO. Thermodynamic analysis of chemical reactions in the systems $\mathrm{FeSi}-\mathrm{Ca}(\mathrm{OH})_{2}-\mathrm{H}_{2} \mathrm{O}$ and $\mathrm{FeSi}_{2}-\mathrm{Ca}(\mathrm{OH})_{2}-\mathrm{H}_{2} \mathrm{O}$. Voprosy Khimii i Khimicheskoi Tekhnologii. 2019; (6): 136-143. doi: 10.32434/0321-4095-2019-127-6-136-143.

6. Salej AA, Snezhko LA, Sigunov AA, Kravchenko TV, Hmarskaja LA, Kononovich MN. Termodinamicheskii analiz reaktsii $\mathrm{v}$ sisteme $\mathrm{Si}-\mathrm{Ca}(\mathrm{OH})_{2}$ [Thermodynamic analysis of reactions in the $\mathrm{Si}-\mathrm{Ca}(\mathrm{OH})_{2}$ system]. Vestnik Nats Tekhn Un-ta «KhPI». 2015; 30(1139): 85-91. (in Russian).

7. Yermolenko I, Ved' M, Karakurkchi A, Proskurina V, Sknar I, Kozlov Y, et al. Research into influence of the electrolysis modes on the composition of galvanic $\mathrm{Fe}-\mathrm{Co}-\mathrm{Mo}$ coatings. East Eur J Enterprise Technol. 2017; 3(12): 9-15.

doi: $10.15587 / 1729-4061.2017 .103100$.

8. Minakova NA, Zaichuk AV, Belyi YI. The structure of borate glass. Glass Ceram. 2008; 65: 70-73. doi: 10.1007/s10717-008-9017-2.

9. Butt YuM. Khimicheskaya tekhnologiya vyazhushchikh materialov [Chemical technology of binders]. Moscow: Vysshaya Shkola; 1980. 472 p. (in Russian)

10. Kasymova MT, Dyykanbaeva NA. Issledovaniye struktury i fazovogo sostava neavtoklavnogo gazobetona [Investigation of the structure and phase composition of nonautoclave aerated concrete]. Izvestiya Vuzov Stroitelstvo. 2019; (7) 16-22. (in Russian).

11. Logvinkov SM, Shabanova GN, Korohodska AN, Khrystych EV. Modified alumina cement with high service properties. China's Refract. 2016; 25(4): 1-5.

12. Dolotova RG, Vereshchagin VI, Smirenskaya VN. Protsessy fazoobrazovaniya i formirovaniya poristoi strukturi gazobetona na osnove portlandtsementa $\mathrm{s}$ ispolzovaniem polevoshpatovo-kvartsevogo peska i volokon asbesta [Processes of phase formation and formation of a porous structure of aerated concrete based on Portland cement using feldspar-quartz sand and asbestos fibers]. Izvestiya Tomskogo Politekhnicheskogo Universiteta. 2011; (3): 47-51. (in Russian).

13. Kaftaeva MV, Rakhimbaev SM, Pospelova EA. Issledovaniye fazovogo sostava avtoklavnykh yacheistykh betonov [Investigation of the phase composition of autoclaved cellular concrete]. Sovremennyye Problemy Nauki i Obrazovaniya. 2013; (5). (in Russian). 